\title{
Importance of particle formation to reconstructed water column biogenic silica fluxes
}

\author{
Brivaëla Moriceau, ${ }^{1}$ Morgane Gallinari, ${ }^{1}$ Karline Soetaert, ${ }^{1}$ and Olivier Ragueneau ${ }^{1}$ \\ Received 9 August 2006; revised 23 April 2007; accepted 11 May 2007; published 24 August 2007.
}

[1] The particles sinking out of the ocean's surface layer are made up of a mixture of living and dead algal cells, fecal pellets, and aggregates, while the parameters used to describe the behavior of biogenic silica $\left(\mathrm{bSiO}_{2}\right)$ in today's models are experimentally determined on freely suspended diatoms (FC). In a simple advection-reaction model we combine sinking rates of $\mathrm{FC}$, zooplankton fecal pellets, and aggregates with recent measurements of $\mathrm{bSiO}_{2}$ dissolution to reconstruct theoretical downward profiles of $\mathrm{bSiO}_{2}$ fluxes at eight sites in the world ocean. Statistical analyses showed that sinking and dissolution parameters for two pools of $\mathrm{bSiO}_{2}$ are required to model particle fluxes accurately. The two-pool model results confirm the importance of seasonality for particle formation and its connection to the percentage of the $\mathrm{bSiO}_{2}$ production that reaches the seafloor. The depth of $\mathrm{bSiO}_{2}$ recycling appears to be influenced more by particle formation than by dissolution rates of $\mathrm{bSiO}_{2}$ or the ballast effect of the dense diatom frustules.

Citation: Moriceau, B., M. Gallinari, K. Soetaert, and O. Ragueneau (2007), Importance of particle formation to reconstructed water column biogenic silica fluxes, Global Biogeochem. Cycles, 21, GB3012, doi:10.1029/2006GB002814.

\section{Introduction}

[2] Diatoms form the basis of a short food chain that leads to carbon export to higher trophic levels [Cushing, 1989; Thornton, 2002] and to deeper waters [Buesseler, 1998]. They are an important player in the global carbon cycle because of their participation in an efficient food web and their ability to aggregate [Smetacek, 1999]. Because diatoms require silica to build their frustules, their share in total primary production (PP) depends on the availability of the nutrient silicic acid (DSi) in many regions of the world ocean such as the equatorial Pacific [Dugdale et al., 1995; Leynaert et al., 2001] or the Southern Ocean [Brzezinski et al., 2001; Pondaven et al., 1998]. The availability of DSi in surface waters, in particular relative to other nutrients, is linked to the composition of the source waters in upwelling regions and/or the intensity of biogenic silica $\left(\mathrm{bSiO}_{2}\right)$ recycling in surface waters in other oceanic regions. Depending on the depth of $\mathrm{bSiO}_{2}$ dissolution, diatom production is affected on different timescale. Shallow depth mineralization immediately influences diatom production and phytoplankton dynamics [Officer and Ryther, 1980]. Recycling in intermediate waters [Sarmiento et al., 2004] and/or deep waters [Ragueneau et al., 2000] affects the meridional distribution of DSi or the redistribution of DSi among oceanic basins, respectively, with implications for intermediate to long timescales.A global average of $60 \%$ of the $\mathrm{bSiO}_{2}$ produced in surface waters is recycled

\footnotetext{
${ }^{1}$ Institut Universitaire Européen de la Mer, UMR CNRS 6539, Plouzané, France.

Copyright 2007 by the American Geophysical Union. 0886-6236/07/2006GB002814\$12.00
}

in the first $100 \mathrm{~m}$ [Nelson et al., 1995; Tréguer et al., 1995]. This global mean hides large regional differences [Nelson et al., 1995; Ragueneau et al., 2000, 2002], which cannot be related to any simple trend in production or diatom abundance, nor to any single mechanism known to influence dissolution, such as temperature [Lawson et al., 1978] or bacterial activity [Bidle and Azam, 1999]. The dissolution to production ratio, integrated over the surface layer $\left(\int \mathrm{D}: \int \mathrm{P}\right)$, has been related to the formation of diatom blooms by Brzezinski et al. [2003]; this ratio is lower during blooms, leaving more room for export and deeper recycling. However, the use of global biogeochemical models to reproduce both $\mathrm{DSi}$ and $\mathrm{bSiO}_{2}$ flux profiles in the global ocean is difficult and does not always agree with in situ measurements [Aumont et al., 2003]. We hypothesize that the present difficulty in modeling both the $\mathrm{bSiO}_{2}$ and $\mathrm{DSi}$ profiles of the global ocean are due to underestimating the importance of particle formation. Whereas aggregates and fecal pellets of large grazers are major vehicles for export (review given by Turner [2002] and Thornton [2002]), the parameters used to represent the fate of PP in global ocean models are still measured on freely suspended diatoms.

[3] To test this hypothesis, we developed a simple advectionreaction model using one and then two different pools of particles. The model combines a series of in vitro $\mathrm{bSiO}_{2}$ dissolution experiments undertaken on the different constituents of the flux: freely suspended diatoms (compiled by Van Cappellen et al. [2002]), zooplankton fecal pellets [Schultes, 2004; M. Gallinari et al., unpublished data, 2004] and aggregates [Moriceau et al., 2007] with data on $\mathrm{bSiO}_{2}$ production, export and deep fluxes from 8 biogeochemical provinces of the world ocean (described by Ragueneau et al. [2002]). The $\mathrm{bSiO}_{2}$ downward fluxes are 
Table 1. Range of Sinking Rates and Specific Dissolution Rates Cited in the Literature for Freely Suspended Cells, Aggregates, and Copepods Fecal Pellets

\begin{tabular}{|c|c|c|c|c|c|}
\hline & \multicolumn{2}{|c|}{ Sinking Rate, $\mathrm{m} \mathrm{d}^{-1}$} & \multicolumn{2}{|c|}{ Dissolution Rate, $\mathrm{d}^{-1}$} & \multirow{2}{*}{$\begin{array}{l}\text { Used in } \\
\text { This Study }\end{array}$} \\
\hline & Range & References & Range & References & \\
\hline Cells & $0.2-20$ & $\begin{array}{l}\text { Bienfang [1981], } \\
\text { Mann and Lazier [1996], } \\
\text { Smayda [1970], Turner [2002] }\end{array}$ & $0.005-1.3$ & $\begin{array}{l}\text { Van Cappellen et al. } \\
\text { [2002] }\end{array}$ & 0.044 \\
\hline Aggregates & $1-370$ & $\begin{array}{l}\text { Alldredge and Gotschalk } \\
\text { [1988], Ridgwell et al. [2002] }\end{array}$ & $0.012-0.056$ & Moriceau et al. [2007] & 0.022 \\
\hline $\begin{array}{l}\text { Copepod } \\
\text { fecal pellets }\end{array}$ & $5-220$ & $\begin{array}{l}\text { Turner [2002], Wassmann } \\
\text { et al. [1999] }\end{array}$ & $0.003-0.027$ & $\begin{array}{l}\text { Schultes [2004], } \\
\text { M. Gallinari et al., } \\
\text { unpublished data, } 2004\end{array}$ & 0.022 \\
\hline
\end{tabular}

${ }^{a}$ The column "Used in This Study" gives the dissolution values actually used herein. For the slow sinking/fast dissolving group (FC), we used the mean value given by Van Cappellen et al. [2002] from a compilation of studies, whereas for the LP (aggregates + fecal pellets) the rates are calculated from the average value given by Van Cappellen et al. [2002] divided by the factor of two which is the average decrease in dissolution rates observed when cells are incorporated into fecal pellets and aggregates [Schultes, 2004; Moriceau et al., 2007; M. Gallinari et al., unpublished data, 2004].

modeled to fit the downward flux data at the eight sites. This allows us to derive important information about particle formation in the upper ocean. The composition of the $\mathrm{bSiO}_{2}$ fluxes in terms of large or small particles and, the sinking and specific $\mathrm{bSiO}_{2}$ dissolution rates of each component help to unravel mechanisms involved in the spatial variability of the intensity and depth of $\mathrm{bSiO}_{2}$ dissolution.

\section{Approach: From Laboratory Experiments to a Virtual Water Column}

\subsection{Experimental Measurements}

[4] The flux of matter sinking through the water column is mainly composed of freely suspended phytoplankton cells, aggregates, and zooplankton fecal pellets [Turner, 2002; Thornton, 2002]. Specific $\mathrm{bSiO}_{2}$ dissolution rates are usually measured experimentally on freely suspended diatoms (compiled by Van Cappellen et al. [2002]). Recently, however, specific dissolution rates of $\mathrm{bSiO}_{2}$ incorporated into aggregates [Moriceau et al., 2007] and fecal pellets [Schultes, 2004; M. Gallinari et al., unpublished data, 2004] have been measured in the laboratory and shown to be about half the rates measured on freely suspended diatoms (Table 1). Including the dissolution rates of all particle types in models should enable us to predict the $\mathrm{bSiO}_{2}$ sedimentation flux more precisely. Here we consider a model of $\mathrm{bSiO}_{2}$ flux with depth that includes two types of particles (free diatom cells: FC, and large particles: LP). We can keep the model simple with only two particle types by assuming that the sinking rates and specific $\mathrm{bSiO}_{2}$ dissolution rates of aggregates and fecal pellets are similar as is demonstrated in Table 1. The FC group has the slow sinking rate and fast specific $\mathrm{bSiO}_{2}$ dissolution rate characteristic of free diatom cells. The LP group has faster sinking rates than the $\mathrm{FC}$ and half the specific $\mathrm{bSiO}_{2}$ dissolution rate. For comparison, the model was first run using only one type of particle with sinking properties and $\mathrm{bSiO}_{2}$ dissolution rates between those of FC and LP particles as described below.

[5] The data used for this study were collected in eight biogeochemical provinces of the world ocean, for which annual measurements of $\mathrm{bSiO}_{2}$ production, export and deep fluxes (at 2 depths) are available (data from Ragueneau et al. [2002]). In this data set, export fluxes (at $200 \mathrm{~m}$ ) were derived from models or from sediment trap measurements while deeper water fluxes (1000 and $3000 \mathrm{~m}$ depth) were measured using sediment traps. Two sites are located in the Equatorial (EqPac) and North Pacific (OSP), and two in the North Atlantic Ocean (PAP and BATS). Four are located in the Southern Ocean: one north of the Polar Front in the Pacific sector (NACC), two in the Polar Front Zone of the Atlantic (APFA) and Pacific (APFP) sectors, and one just south of the Polar Front in the Indian sector (POOZ) (see positions in Table 2). Four data points can be fitted for each site, providing a total of 32 data points.

\subsection{Model Description}

[6] The concentration profiles of $\mathrm{bSiO}_{2}$ for each particle pool i (LP or FC) can be described by a simple advectionreaction model (equation (1)),

$$
\frac{\partial \mathrm{bSiO}}{\partial \mathrm{t}}=-\mathrm{S}_{\mathrm{i}} \cdot \frac{\partial \mathrm{bSiO}}{\partial \mathrm{z}}-\mathrm{k}_{\mathrm{i}}(\mathrm{T}) \cdot \mathrm{bSiO}_{2 \mathrm{i}},
$$

where $\mathrm{t}$ is time $(\mathrm{d}), \mathrm{z}$ depth $(\mathrm{m}), \mathrm{S}_{\mathrm{i}}$ is the sinking rate $\left(\mathrm{m} \mathrm{d}^{-1}\right)$, and $\mathrm{k}_{\mathrm{i}}(\mathrm{T})$ is the (temperature-dependent) first-order specific $\mathrm{bSiO}_{2}$ dissolution rate $\left(\mathrm{d}^{-1}\right)$. Such first-order dissolution of $\mathrm{bSiO}_{2}$ is often observed in batch experiments and leads to a simple exponential increase in the DSi concentration as a function of time [e.g., Greenwood et al.,

[7] Assuming steady state $\left(\frac{\partial \mathrm{bSiO}_{2 i}}{\partial \mathrm{t}}=0\right)$, and constant sinking and dissolution rates, the concentration $\left(\mathrm{mmol} \mathrm{m}^{-3}\right)$ and flux of $\mathrm{bSiO}_{2}\left(\mathrm{mmol} \mathrm{m}{ }^{-2} \mathrm{~d}^{-1}\right)$ at each water column depth (z) are given by equation (2):

$$
\mathrm{bSiO}_{2 i}(z)=\mathrm{bSiO}_{2 i}(0) \cdot e^{-\frac{k_{\mathrm{i}}}{\mathrm{s}_{\mathrm{i}}}}
$$

which in terms of the total fluxes for the one-particle model and the two-particle model gives equation (3) and $\left(3^{\prime}\right)$, respectively,

$$
\begin{gathered}
\mathrm{FbSiO}_{2}(z)=\mathrm{PP}_{\mathrm{bSiO}_{2}} \cdot e^{-\frac{\mathrm{k}_{\mathrm{s}}}{\mathrm{s}} \mathrm{z}} \\
\mathrm{FbSiO}_{2}(z)=\mathrm{PP}_{\mathrm{bSiO}_{2}} \cdot\left[\alpha \cdot e^{-\frac{\mathrm{k}_{\mathrm{FC}}}{\mathrm{S} \mathrm{FC}} \cdot z}+(1-\alpha) \cdot e^{-\frac{\mathrm{k}_{\mathrm{LP}}}{\mathrm{s}_{\mathrm{LP}}}} \cdot \mathrm{z}\right.
\end{gathered}
$$


Table 2. Environmental Characteristics and Results of the Two Versions of the Two-Particle Model Calculated to Fit the bSiO ${ }_{2} \mathrm{Flux}$ Profiles at Eight Sites of the Global Ocean ${ }^{\mathrm{a}}$

\begin{tabular}{|c|c|c|c|c|c|c|c|c|}
\hline & POOZ & APFP & $\mathrm{NACC}$ & APFA & OSP & $\mathrm{EqPac}$ & BATS & PAP \\
\hline Latitude & -52 & -60 & -56.9 & -50.1 & 50 & 1 & 28 & 48.8 \\
\hline Longitude & 62 & -170 & -170.1 & 5.8 & -145 & -139 & -67.5 & -16.5 \\
\hline MMLD, m & 259 & 235 & 390 & 180 & 100 & 48 & 100 & 576 \\
\hline SI & 2.80 & 3.75 & 2.80 & 2.70 & 2.50 & 0.33 & 1.30 & 3.00 \\
\hline \multicolumn{9}{|l|}{ Model 2: Two-particle model, global $\mathrm{S}_{\mathrm{FC}}$} \\
\hline Percent $\mathrm{PP}_{\mathrm{bSiO} 2}$ in FC stage $\alpha, \%$ & 80 & 70 & 40 & 20 & 69 & 88 & 83 & 65 \\
\hline $\mathrm{S}_{\mathrm{FC}}, \mathrm{m} \mathrm{d}^{-1}$ & 2.76 & 2.76 & 2.76 & 2.76 & 2.76 & 2.76 & 2.76 & 2.76 \\
\hline Percent $\mathrm{PP}_{\mathrm{bSiO} 2}$ into LP $(1-\alpha), \%$ & 20 & 30 & 60 & 80 & 31 & 12 & 17 & 35 \\
\hline $\mathrm{S}_{\mathrm{LP}}, \mathrm{m} \mathrm{d}^{-1}$ & 470 & 53 & 27 & 47 & 90 & 812 & 92 & 55 \\
\hline \multicolumn{9}{|l|}{ Model 3: Two-particle model, variable $\mathrm{S}_{\mathrm{FC}}$} \\
\hline Percent of $\mathrm{PP}_{\mathrm{bSiO} 2}$ in FC stage $\alpha, \%$ & 68 & 81 & 78 & 17 & 64 & 88 & 83 & 85 \\
\hline $\mathrm{S}_{\mathrm{FC}}, \mathrm{m} \mathrm{d}^{-1}$ & 1.4 & 4.5 & 10.3 & 0.1 & 2 & 0.1 & 0.1 & 6.7 \\
\hline Percent $\mathrm{PP}_{\mathrm{bSiO} 2}$ into LP $(1-\alpha), \%$ & 32 & 19 & 22 & 83 & 36 & 12 & 17 & 15 \\
\hline $\mathrm{S}_{\mathrm{LP}}, \mathrm{m} \mathrm{d}^{-1}$ & 51 & 452 & 242 & 45 & 62 & 500 & 90 & 605 \\
\hline
\end{tabular}

${ }^{a}$ See Figure 1. The depth of the maximum mixed layer (MMLD) and the location of the sites are from Ragueneau et al. [2002]. The seasonality indexes (SI) are calculated following the work of Berger and Wefer [1990]. The last rows depict combinations of sinking rates for FC $\left(\mathrm{S}_{\mathrm{FC}}\right)$ and LP ( $\left.\mathrm{S}_{\mathrm{LP}}\right)$ and percentage of $\mathrm{bSiO}_{2}$ incorporated into the two groups of particles calculated with each version of the two-particle model from the best fits.

where $\alpha$ and $(1-\alpha)$ correspond to $\mathrm{bSiO}_{2}$ production $\left(\mathrm{PP}_{\mathrm{bSiO} 2}\right.$, in $\left.\mathrm{mmol} \mathrm{m} \mathrm{m}^{-2} \mathrm{~d}^{-1}\right)$ in the $\mathrm{FC}$ and the LP groups in the upper layer, respectively.

[8] As temperature is allowed to vary, we use a piecewise approximation to model equation (3). The water column is subdivided into a number of layers (with thickness $\Delta z$ ) in which temperature is assumed constant. Then, for each fraction, the flux at the bottom $(\mathrm{z}+\Delta \mathrm{z})$ and top $(\mathrm{z})$ of this layer are related by

$$
\mathrm{FbSiO}_{2 \mathrm{i}}(\mathrm{z}+\Delta \mathrm{z})=\mathrm{FbSiO}_{2 \mathrm{i}}(\mathrm{z}) \cdot e^{-\frac{\mathrm{ki}(\mathrm{T})}{\mathrm{S}_{\mathrm{i}}} \cdot \Delta \mathrm{z}} .
$$

For the one-particle model the flux at $\mathrm{z}=0$ equals the $\mathrm{bSiO}_{2}$ production $\left(\mathrm{PP}_{\mathrm{bSiO} 2}\right)$, and for the two-particle model the $\mathrm{bSiO}_{2}$ flux at each depth is the sum of the LP and FC fluxes.

$$
\begin{aligned}
& \mathrm{FbSiO}_{2 \mathrm{FC}}(0)=\alpha \cdot \mathrm{PP}_{\mathrm{bSiO}_{2}} \\
& \mathrm{FbSiO}_{2 \mathrm{LP}}(0)=(1-\alpha) \cdot \mathrm{PP}_{\mathrm{bSiO}_{2}} \\
& \mathrm{FbSiO}_{2 \text { TOT }}(z)=\mathrm{FbSiO}_{2} \mathrm{FC}(z)+\mathrm{FbSiO}_{2 \mathrm{LP}}(\mathrm{z}) .
\end{aligned}
$$

[9] In these equations, $\mathrm{FbSiO}_{2 \text { тот }}(\mathrm{z})$ is the flux of total $\mathrm{bSiO}_{2}$ in mmol m $\mathrm{m}^{-2} \mathrm{~d}^{-1}$ at depth $\mathrm{z} ; \mathrm{PP}_{\mathrm{bSiO} 2}$ is the production flux of $\mathrm{bSiO}_{2}$ in mmol m $\mathrm{m}^{-2} \mathrm{~d}^{-1} ; \mathrm{FbSiO}_{2} \mathrm{FC}(\mathrm{z})$ and $\mathrm{FbSiO}_{2}$ LP( $(\mathrm{z})$ are the fluxes of $\mathrm{bSiO}_{2}$ in the $\mathrm{FC}$ and LP groups at depth $z$ respectively. Here $\mathrm{k}_{\mathrm{FC}}(\mathrm{T})$ and $\mathrm{k}_{\mathrm{LP}}(\mathrm{T})$ are the specific $\mathrm{bSiO}_{2}$ dissolution rates in $\mathrm{d}^{-1}$ given in the literature for FC particles (Table 1) and corrected by the factor of 2 less that was measured experimentally for LP particles. Rates were also corrected for temperature, according to equation (6) from Rickert et al. [2002]; temperature profiles of the water column at each site were from the NODC (Levitus) World Ocean Atlas 1998 (http:// www.cdc.noaa.gov/).

$$
\ln \left(\mathrm{k}_{\mathrm{z}}\left(\mathrm{T}_{2}\right)\right)=\ln \left(\mathrm{k}_{1}\right)+\frac{\mathrm{E}_{\mathrm{app}}}{\mathrm{R}} \times\left(\frac{1}{\mathrm{~T}_{1}}-\frac{1}{\mathrm{~T}_{2}}\right)
$$

where $\mathrm{k}_{1}$ is the specific $\mathrm{bSiO}_{2}$ dissolution rate in $\mathrm{d}^{-1}$ measured in controlled conditions in the laboratory; $\mathrm{T}_{1}$ is the experimental temperature in degrees Kelvin $(286.15 \mathrm{~K})$; $\mathrm{k}_{\mathrm{z}}\left(\mathrm{T}_{2}\right)$ is the rate recalculated for the depth $\mathrm{z}$ at the in situ temperature $\mathrm{T}_{2}$; and $\mathrm{Eapp} / \mathrm{R}=7211^{\circ} \mathrm{K}$.

[10] To facilitate comparison among sites, the total flux is normalized to the production flux to obtain a profile of $\mathrm{bSiO}_{2}$ flux expressed in $\%$ of $\mathrm{bSiO}_{2}$ production. For both models we have

$$
\% \mathrm{FbSiO}_{2}(z)=\frac{\mathrm{FbSiO}_{2 \text { tot }}(z)}{\mathrm{PP}_{\mathrm{bSiO}_{2}}} \times 100,
$$

which for the two-particle model becomes

$$
\% \mathrm{FbSiO}_{2}(z)=\frac{\mathrm{FbSiO}_{2 \mathrm{FC}}(z)+\mathrm{FbSiO}_{2 \mathrm{LP}}(z)}{\mathrm{PP}_{\mathrm{bSiO}_{2}}} \times 100
$$

\subsection{Parameter Determination}

[11] As a first step, we applied the one-pool model to fit the $\mathrm{bSiO}_{2}$ flux profiles measured in the field. The specific dissolution rate was set to the value given in Table 1 for FC, and corrected for temperature at each site and depth using equation (6). At each site, the model 1 calculated the $\mathrm{bSiO}_{2}$ sinking rate required to fit the in situ $\mathrm{bSiO}_{2}$ flux data. Note that the fit is not improved when the model uses LP specific dissolution rates instead of $\mathrm{k}_{\mathrm{FC}}$ nor an average of the two values.

[12] In a second step, $\mathrm{bSiO}_{2}$ specific dissolution rates and the sinking rates for two pools of particles were included in the model (model 2). Specific $\mathrm{bSiO}_{2}$ dissolution rates of $\mathrm{FC}$ and LP were set to values presented in Table 1 and corrected for in situ temperature at each depth using equation (6). The model 2 calculated a global sinking rate for $\mathrm{FC}$ particles $\left(\mathrm{S}_{\mathrm{FC}}\right)$ for all sites, one LP sinking rate per site and the percent of $\mathrm{bSiO}_{2}$ from the production which is incorporated into large particles $(1-\alpha)$ or stays freely suspended $(\alpha)$. 

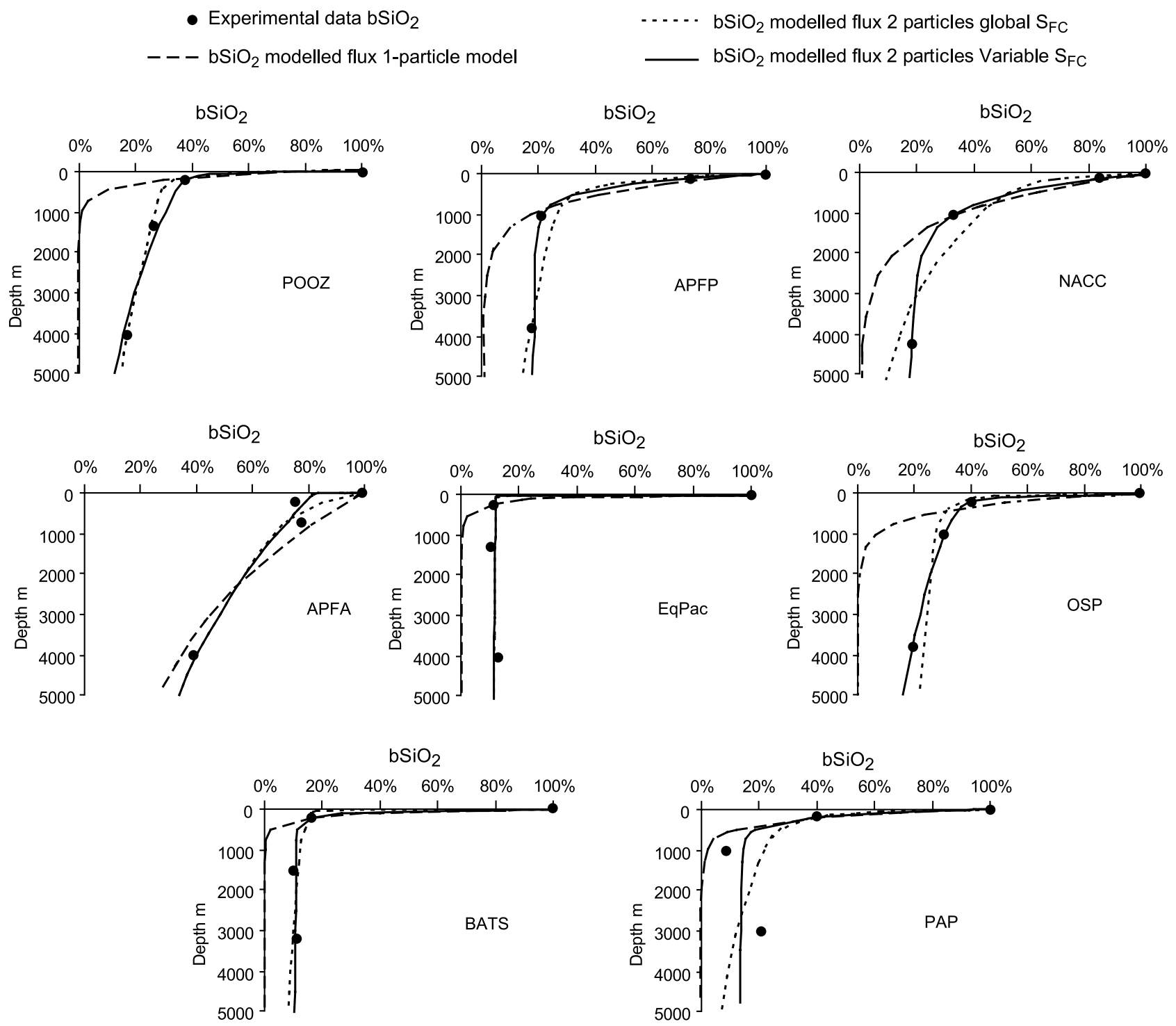

Figure 1. Best fits (lines) of the three versions of the models and in situ (dots) $\mathrm{bSiO}_{2}$ flux profiles, for eight sites in the global ocean described by Ragueneau et al. [2002] (positions given in Table 2). The dashed lines are the fits obtained from the one-particle model, the dotted lines describe the $\mathrm{bSiO}_{2}$ fluxes calculated with the two-particle model that uses a global $\mathrm{S}_{\mathrm{FC}}$, and the solid lines depict the $\mathrm{bSiO}_{2}$ profiles obtained from the two-particle model that uses a variable $\mathrm{S}_{\mathrm{FC}}$ calculated at each site.

[13] Finally, in a third step (model 3), the parameter $\mathrm{S}_{\mathrm{FC}}$ was allowed to vary at each site.

[14] In the three versions of the model, parameters were calculated by minimizing the sum of the square residuals using the Excel Solver and the GRG method (Generalized Reduced Gradient). These calculations were tested for many initial values because the algorithm used is nonlinear. Best fits to the data using the three model versions are shown for each of the eight sites in Figure 1.

\subsection{Statistical Comparison of the One-Particle and Two-Particle Models}

[15] We used an $\mathrm{F}$ test to compare the three versions of the model. The null hypothesis considers that adding complexity to the model does not significantly decrease the sum of the square residuals between model and observed data (SSR). The calculated $\mathrm{F}$ value is obtained using equation (8) and compared to the $\mathrm{F}$ test critical value.

$$
\mathrm{F}=(\operatorname{SSR} 1-\operatorname{SSR} 2)(\mathrm{df} 1-\mathrm{df} 2) /(\operatorname{SSR} 2 / \mathrm{df} 2) .
$$

SSR1 and SSR2 are the sum of the square residuals between the modeled and the experimental values; df 1 and df 2 are the degrees of freedom of the different versions of the model calculated as follows.

$$
\mathrm{dfi}=\mathrm{E}-\mathrm{P}-1,
$$



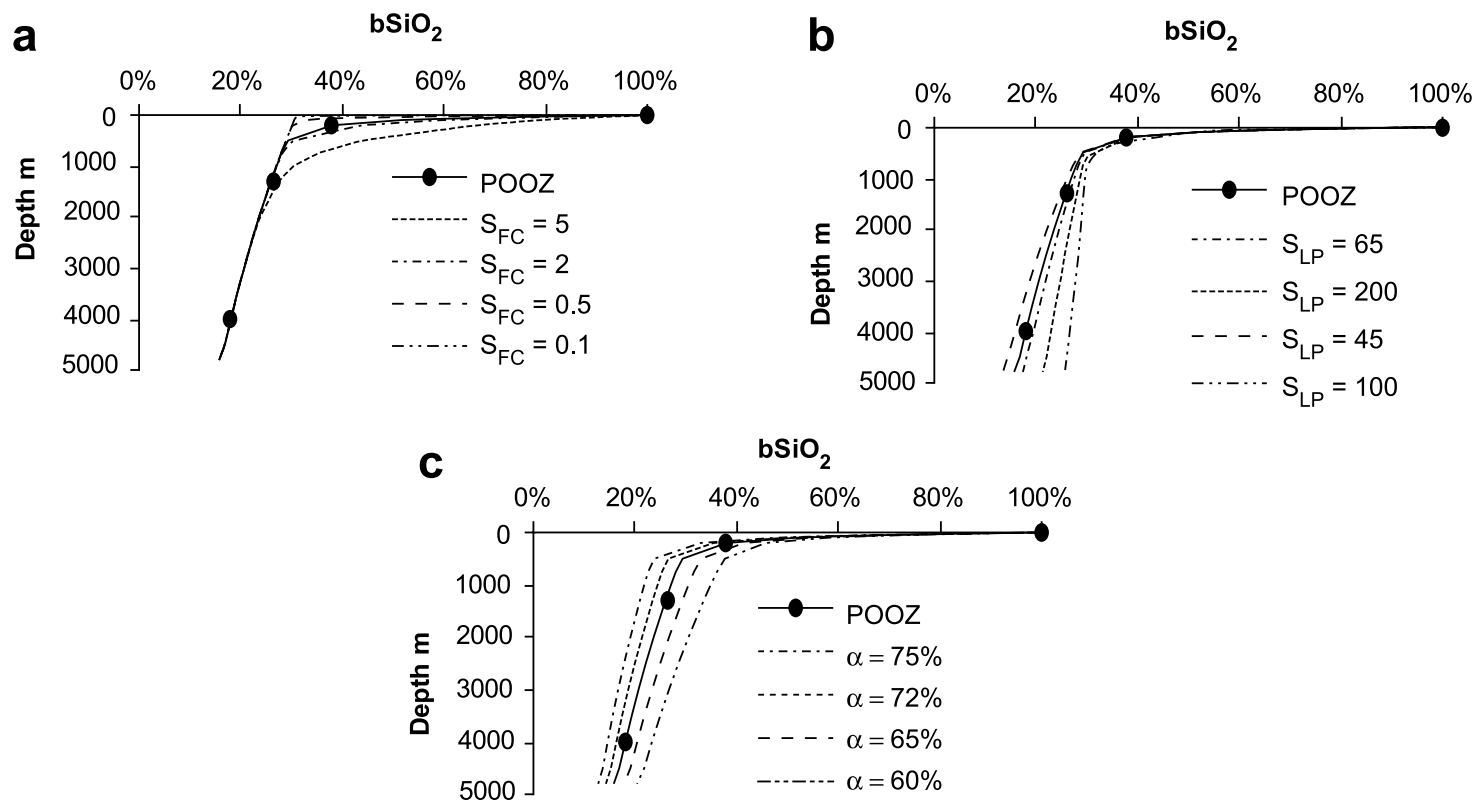

Figure 2. Sensitivity of the model, represented by successive variation of parameters. (a) Sensitivity of the model to the sinking rate of the slow sinking/fast dissolving particle $\mathrm{S}_{\mathrm{FC}}$, with $\mathrm{S}_{\mathrm{LP}}$ set at $51 \mathrm{~m} \mathrm{~d}^{-1}$ and $\alpha$ at $68 \%$. (b) Sensitivity of the model to the sinking rate of the fast sinking/slow dissolving particle $\mathrm{S}_{\mathrm{LP}}$, with $\mathrm{S}_{\mathrm{FC}}$ set at $1.4 \mathrm{~m} \mathrm{~d}^{-1}$ and $\alpha$ at $68 \%$. (c) Sensitivity of the model to the repartition of the $\mathrm{bSiO}_{2}$ between the FC group $\alpha$, and the LP group $(1-\alpha)$, with $\mathrm{S}_{\mathrm{LP}}$ set at $51 \mathrm{~m} \mathrm{~d}^{-1}$ and $\mathrm{S}_{\mathrm{FC}}$ at $1.4 \mathrm{~m} \mathrm{~d}^{-1}$. The graphs represent the results of the test for the $\mathrm{POOZ}$ site, the full circles and the full lines in each graph represent the in situ measurements of the $\mathrm{bSiO}_{2}$ fluxes and the results of the model 3 .

where $\mathrm{E}$ is the number of observed values the models has to fit (4 data for each of the 8 sites), and $\mathrm{P}$ is the number of variable parameters used to optimize the fit.

[16] The F test was first applied to compare the one-particle model (hereafter referred to as model 1) to a two-particle model using a global $\mathrm{S}_{\mathrm{FC}}$ (model 2). Next, we compared two versions of the two-particle model, one using a global $\mathrm{S}_{\mathrm{FC}}$ (model 2 again) and one using a variable $\mathrm{S}_{\mathrm{FC}}$ at each site (model 3). When the model considered only one type of particle, it had 23 degrees of freedom. Model 2 used 17 parameters, providing 14 degrees of freedom. Finally, model 3 had 7 degrees of freedom.

\section{Results}

\subsection{Comparison of the Model Versions: Importance of Particle Formation}

[17] Figure 1 shows the reconstructed $\mathrm{bSiO}_{2}$ profiles at the eight sites for the three versions of the model. Model 1 is clearly not able to fit the experimental data at any of the eight sites. When the model uses two different pools of $\mathrm{bSiO}_{2}$ but only one global $\mathrm{S}_{\mathrm{FC}}$, the $\mathrm{bSiO}_{2}$ profiles are close to the measured values except for APFP, NACC and PAP. The F-test determined, at a 99\% confidence level, that model 2 provides a better fit to the data than model 1 . Thus the use of a global $\mathrm{S}_{\mathrm{FC}}$ of $2.76 \mathrm{~m} \mathrm{~d}^{-1}$ (Table 2) is a good approximation. Note that at the PAP site, the flux at $1000 \mathrm{~m}$ is low compared to the flux at $3000 \mathrm{~m}$ and can be explained by the presence of swimmers in the trap [Lampitt et al., 2001].
[18] Model 2, which considered a global FC sinking rate $\left(\mathrm{S}_{\mathrm{FC}}\right)$, gives more degrees of freedom than model 1, but the use of a global $\mathrm{S}_{\mathrm{FC}}$ is also an oversimplification. Indeed, for the PAP site in the northeast Atlantic Ocean, and for the NACC and APFP sites located in the Pacific sector of the Southern Ocean (north of the Polar Front and on the Polar Front, respectively), this approach does not fit the data closely. To improve the reconstruction of these $\mathrm{bSiO}_{2}$ fluxes, the model has to use a $\mathrm{S}_{\mathrm{FC}}$ higher than the global one. Reconstructions of the Southern Ocean profiles are generally improved by using model 3 with a varying $\mathrm{S}_{\mathrm{FC}}$ (Figure 1). The F-test also favors model 3 over model 2 at the $95 \%$ confidence level. At the annual scale, FC sinking rates can be classified into two groups: fast $\mathrm{S}_{\mathrm{FC}}$ in the Southern Ocean and PAP site and slow $\mathrm{S}_{\mathrm{FC}}$ in the rest of the world. This trend may well reflect the production of large, fast sinking diatoms commonly observed in the Southern Ocean [Kemp et al., 2006].

[19] Freely suspended diatoms and large particles have such different sinking rates and specific $\mathrm{bSiO}_{2}$ dissolution rates that parameters of the two groups of particles must be considered to correctly reconstruct $\mathrm{bSiO}_{2}$ flux profiles. The role and importance of each particle type is confirmed by a sensitivity analysis performed on the profiles using model 3 for the sinking rates of the two particles (shown for POOZ, Figure 2). Profiles of $\mathrm{bSiO}_{2}$ fluxes are quite sensitive to variation in sinking rates: in the upper $1000 \mathrm{~m}$ the profile is mostly affected by the sinking rate of FC whereas deeper, the profile is more sensitive to variation of the LP sinking rate. The composition of the flux in the upper layer 
Table 3. Residence Times of the Particles in the Mixing Layer (ML) in Days Calculated Considering Only Dissolution Processes and Considering Only Sedimentation Rates at the Eight Sites ${ }^{\text {a }}$

\begin{tabular}{|c|c|c|c|c|c|c|c|c|}
\hline & POOZ & APFP & NACC & APFA & OSP & $\mathrm{EqPac}$ & BATS & PAP \\
\hline \multicolumn{9}{|c|}{ Residence time of FC in surface layer } \\
\hline Considering only sinking & 0.7 & 0.2 & 0.1 & 10 & 0.5 & 10 & 10 & 0.15 \\
\hline Considering only dissolution & 56 & 56 & 43 & 60 & 36 & 8 & 8 & 21 \\
\hline \multicolumn{9}{|c|}{ Residence time of LP in surface layer } \\
\hline Considering only sinking & 0.020 & 0.002 & 0.004 & 0.022 & 0.016 & 0.002 & 0.011 & 0.002 \\
\hline Considering only dissolution & 113 & 113 & 86 & 121 & 71 & 15 & 17 & 42 \\
\hline
\end{tabular}

${ }^{a}$ To calculate the residence time of the particles considering only sinking processes, the sinking rates are normalized by the depth of the mixed layer (MMLD) as given in Table 2. The residence times of the particles in the mixed layer considering only dissolution processes are equal to $1 / \mathrm{k}(\mathrm{T})$, with $\mathrm{k}(\mathrm{T})$ the specific dissolution rates corrected for temperature at each site.

(parameter $\alpha$ ) is well constrained, as when the contribution of FC and LP changes by only $5-10 \%$, the resulting profile of $\mathrm{bSiO}_{2}$ flux significantly differs from the one measured (Figure 2c).

\subsection{Model Outputs}

[20] For the eight sites, model 3 provides sinking rates ranging from 45 to $605 \mathrm{~m} \mathrm{~d}^{-1}$ for the LP and from 0.1 to $10.4 \mathrm{~m} \mathrm{~d}^{-1}$ for the FC (Table 2 and Figure 1), consistent with ranges found in the literature (Table 1). The sinking rates calculated by model 3 confirm the prevalence of aggregates and fecal pellets in the LP group (see values and references in Table 1) and the fact that the FC group must be essentially composed of freely suspended diatoms, small and large. Note that the two-particle models (models 2 and 3) cannot always strictly separate LP and FC using $\mathrm{bSiO}_{2}$ sinking and specific dissolution rates. For the two sites located in the Southern Ocean (APFP and NACC) and for PAP, model 3 produces faster FC sinking rates and a faster LP sinking rates than those calculated by model 2 . The $\mathrm{S}_{\mathrm{FC}}$ calculated by the model 2 is in these cases lowered by the other sites' $\mathrm{S}_{\mathrm{FC}}$. The difference between the results of the two models for APFP, NACC and PAP shows the importance of a third group of particles that is included in LP in model 2 results and in FC in model 3 results. Large diatoms that have been observed in areas like the Southern Ocean, Gulf of California, and North Pacific Gyre [Kemp et al., 2000, 2006] apparently dominate the production of APFP, NACC and PAP. Following the same argument, the very low $\mathrm{S}_{\mathrm{LP}}$ and $\mathrm{S}_{\mathrm{FC}}$ calculated by model 3 for $\mathrm{APFA}$ and POOZ suggest simultaneous production of small and large diatoms. Therefore there are really three groups of particles (LP, freely suspended large cells, and freely suspended small cells); however, the large, freely suspended diatoms have been included in the LP group here as the best compromise since the model can only account for two groups of particles.

[21] Also, even if not shown here, giant aggregates with small and even null sinking rates such as those observed by Rinaldi et al. [1995] would certainly be integrated into the FC group of particles.

\section{Discussion}

\subsection{Particle Formation: A Major Factor Determining $\mathrm{bSiO}_{2}$ Export and Recycling}

[22] In their global analysis of $\mathrm{bSiO}_{2}$ production and dissolution, Brzezinski et al. [2003] demonstrated that the dissolution to production ratio integrated over the surface layer $\left(\int \mathrm{D}: \int \mathrm{P}\right)$ is low under bloom conditions, leaving ample room for net export. They underlined the importance of considering dissolution when determining export of matter. Using the model results, we compare the importance of the two processes, sinking and dissolution, by calculating particle residence times in the mixed layer at each site with only sinking or only dissolution considered (Table 3 ). The comparison of these $\mathrm{bSiO}_{2}$ residence times in surface waters suggests that this global data set of $\mathrm{bSiO}_{2}$ production and dissolution cannot ignore particle formation. Sinking rates of large particles act on much shorter timescales than dissolution rates, so, rather than having the export determined by the intensity of the recycling, the intensity of export $\left(1-\int \mathrm{D}: \int \mathrm{P}\right)$ is linked to the rate of large particle formation and drives the intensity of shallow-water recycling. The rate at which diatoms are incorporated into large particles will determine how rapidly exported they are as their fast sinking rates leave no time for dissolution to occur in surface waters. In such cases, the dissolution depth is translated downward. The recycling intensity in surface waters depends first on the ability of diatoms to remain as single cells and secondly on factors such as temperature [Bidle et al., 2002; Fujii and Chai, 2005; Lawson et al., 1978] and bacterial activity [Bidle and Azam, 1999] which control their fate in surface waters.

[23] Thus we suggest that low $\int \mathrm{D}: \int \mathrm{P}$ ratios under bloom conditions [Brzezinski et al., 2003] are caused by a rapid export of bloom diatoms [Buesseler, 1998], which extracts $\mathrm{bSiO}_{2}$ from the surface waters where intense recycling generally occurs under nonbloom conditions. Recognizing the importance of seasonality to the sinking of particles, we calculated the seasonality index of each site as defined by Berger and Wefer [1990] (Table 2) as six minus the number of months necessary to generate one half of the annual productivity when the data are ordered from the most productive to the least productive month (the 'production half-time'). Considering productivity, the eight sites could be classified in three groups [Berger and Wefer, 1990]: $\mathrm{EqPac}$ and BATS have constant productivity (seasonality index close to 0); OSP, APFA, NACC, POOZ, PAP have sinusoidal production (seasonality index between 2 and 3) and APFP has a strong seasonal peak in productivity (seasonality index $>3.5$ ). As shown in Figure 3, sites exhibiting the lowest seasonality (EqPac, BATS) also exhibit the lowest export at $100 \mathrm{~m}$ (i.e., low $\left.1-\int \mathrm{D}: \int \mathrm{P}\right)$. Conversely, sites with higher seasonality (APFP, NACC and 


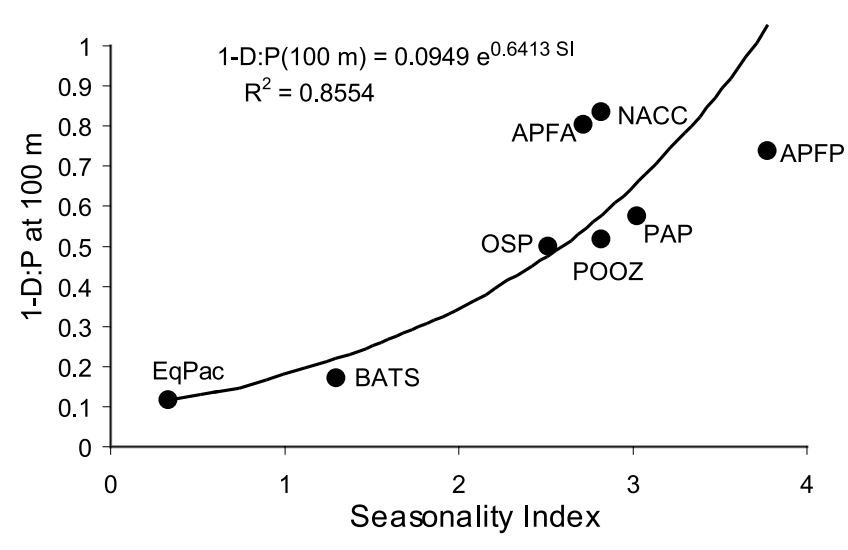

Figure 3. Importance of the seasonality. The 1- $\int \mathrm{D}: \int \mathrm{P}$ at $100 \mathrm{~m}$ is calculated from the model outputs as a function of the seasonality index [Berger and Wefer, 1990]. The site names are given near each corresponding point.

APFA) display a larger 1- $\int \mathrm{D}: \int \mathrm{P}$ at $100 \mathrm{~m}$. Even if seasonality is not the only important factor, Figure 3 confirms its major role in particle formation. Indeed grazing and aggregation processes are more abundant at the end of a bloom [Buesseler, 1998] and consequently the export of matter out of the surface layer is also increased. To properly model diatom export versus recycling, further research efforts must focus not only on dissolution properties, but perhaps more importantly, on representing particle formation during bloom termination.

[24] Another implication of our model results concerns the ballast theory. Armstrong et al. [2002] established a correlation between organic carbon and ballast $\left(\mathrm{bSiO}_{2}\right.$, $\mathrm{CaCO}_{3}$ ) fluxes below the mixing layer. On the basis of this model, Klaas and Archer [2002] concluded that organic carbon is carried into the deeper waters preferentially by calcium carbonate, which has a higher density $\left(2.71 \mathrm{~g} \mathrm{~cm}^{-3}\right)$ than opal $\left(2.1 \mathrm{~g} \mathrm{~cm}^{-3}\right)$. Passow [2004] proposed the inverse of this hypothesis, that carbon, in the form of TEP, could transport organic matter and ballast to the deep sea by promoting aggregation. In APFP, OSP and NACC sites (Table 2), the fast $S_{L P}$ suggested the dominance of large diatoms. At these sites, freely suspended diatoms can be exported from the mixed layer (Table 4) owing to the low temperature at the surface layer and/or high sinking rates.
However, at most other sites, even ballasted with a frustule whose density is twice that of organic matter $\left(1.06 \mathrm{~g} \mathrm{~cm}^{-3}\right)$, a single diatom almost completely dissolves in the upper WML. This observation calls for more caution when considering the ballast theory and emphasizes once again the importance of bloom-ending processes to explain sedimentation fluxes. The fact that POC and ballast fluxes are closely linked below the mixed layer [Armstrong et al., 2002] is not necessarily related only to the higher density of $\mathrm{bSiO}_{2}$ and $\mathrm{CaCO}_{3}$ compared to that of organic matter. The efficiency of sedimentation depends primarily on the incorporation of diatoms into large particles like aggregates or fecal pellets (Figure 2c) in the mixed layer; the ballasting of these large particles throughout the whole water column plays a secondary role (Figure $2 b$ ).

\subsection{Implications for the Silicate Pump}

[25] The silicate pump is the process by which $\mathrm{bSiO}_{2}$ is exported from surface waters with a greater efficiency than PON, driving the system toward DSi limitation. According to Dugdale et al. [1995], grazers are the motor of this silicate pump; whereas nitrogen is largely assimilated or recycled by grazers and therefore retained at the surface, $\mathrm{bSiO}_{2}$ is packaged into fast-sinking fecal pellets and exported from the mixed layer. The silicate pump model was developed initially for the Equatorial Pacific [Dugdale and Wilkerson, 1998] and later applied to the Southern Ocean [Brzezinski et al., 2001]. It is based on several assumptions, including that $\mathrm{bSiO}_{2}$ dissolution in surface waters is negligible [Dugdale et al., 1995]. Our results clearly contradict this assumption at the EqPac site [Dugdale and Wilkerson, 1998]. EqPac is the site with the shallowest recycling in our model output (Figure 1), as observed previously in the field [Blain et al., 1999]. The EqPac site is well known for its low export efficiency [Buesseler, 1998], possibly related to its small seasonal variability (Table 2 and Figure 3). Consequently, the fraction of $\mathrm{bSiO}_{2}$ production incorporated into large particles by aggregation/fecal pellet production is lowest at the EqPac site on an annual basis (Table 2). Our results (Table 4) suggest that the vast majority of the diatoms remain as single cells in surface waters, and $88 \%$ dissolve before reaching the base of the mixed layer (on average, $50 \mathrm{~m}$ ). This extensive dissolution is consistent with the high temperatures (i.e., high dissolution rate) and bacterial activity (i.e.,

Table 4. The $\mathrm{bSiO}_{2}$ Fluxes of the Eight Sites at the Maximum Mixed Layer Depth (MMLD), in Terms of Percent of Total $\mathrm{bSiO}_{2}$ Production at the Surface Layer $\left(\mathrm{PP}_{\mathrm{bSiO}}\right)$, Contribution of the Slow Sinking/Fast Dissolving Group (FC) to the Percent of $\mathrm{PP}_{\mathrm{bSiO} 2}$ That Reaches This Depth, and Percent of $\mathrm{PP}_{\mathrm{bSiO} 2}$ That Sinks Down to the Seafloor ${ }^{\mathrm{a}}$

\begin{tabular}{|c|c|c|c|c|c|c|c|c|}
\hline & POOZ & APFP & NACC & APFA & OSP & $\mathrm{EqPac}$ & BATS & PAP \\
\hline $\begin{array}{l}\mathrm{bSiO}_{2} \text { flux at MMLD, } \\
\% \text { of the } \mathrm{PP}_{\mathrm{bSiO} 2}\end{array}$ & 34 & 53 & 58 & 80 & 50 & 12 & 16 & 18 \\
\hline $\begin{array}{l}\mathrm{bSiO}_{2} \text { flux on } \mathrm{FC} \text { stage } \\
\text { at the MMLD, } \% \text { of the } \\
\mathrm{PP}_{\mathrm{bSiO}_{2}}\end{array}$ & 4 & 34 & 36 & 0 & 16 & 0 & 0 & 3 \\
\hline $\begin{array}{l}\mathrm{bSiO}_{2} \text { flux at the seafloor, } \\
\% \text { of the } \mathrm{PP}_{\mathrm{bSiO} 2}\end{array}$ & 17 & 18 & 18 & 37 & 19 & 11 & 7 & 14 \\
\hline
\end{tabular}

${ }^{\mathrm{a}}$ For MMLD, see also Table 2. 


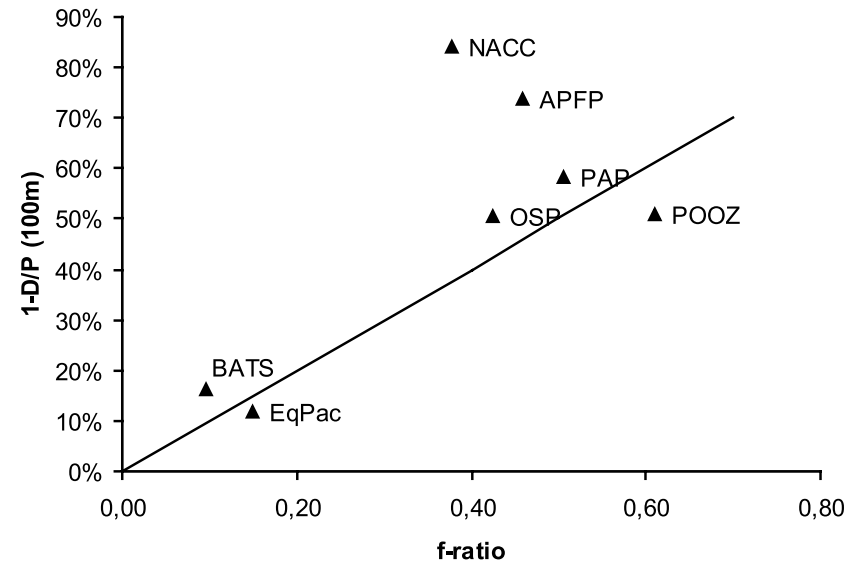

Figure 4. The 1- $\int \mathrm{D}: \int \mathrm{P}$ calculated at $100 \mathrm{~m}$ with the model 3 versus the f-ratios. The f-ratios are from Nelson et al. [2002] for the Southern Ocean and Falkowski et al. [2003] for the other sites. The names of seven of the eight sites are indicated near the corresponding point. APFA site is not in the graph as no f-ratio is available at this site. The solid line delimits the zones where f-ratio is higher or lower than 1- $\int \mathrm{D}: \int \mathrm{P}$ at $100 \mathrm{~m}$ which gives an indication of the strength of the silica pump.

fast removal of protective organic coatings) encountered in these equatorial waters [Bidle et al., 2002]. It is important to note that these are annual fluxes. Episodic events such as Tropical Instability Waves have been shown to trigger intense diatom concentrations at fronts [Yoder et al., 1994], leading to massive sinking of algal material and the formation of large flocs of phytodetritus on the seafloor [Smith et al., 1996]. However, although these episodes may be very important for sustaining life in the mesopelagic and at the sediment-water interface [C. R. Smith et al., 2002; K. L. Smith et al., 2002], or for formation of paleoceanographic records [Ragueneau et al., 2000], our results suggest that they do not contribute appreciably to annual $\mathrm{POC}$ and $\mathrm{bSiO}_{2}$ fluxes in oligotrophic ecosystems.

[26] Brzezinski et al. [2003] have suggested that a measure of the strength of the silicate pump can be obtained by comparing 1- $\int \mathrm{D}: \int \mathrm{P}$ for $\mathrm{Si}$ with the f-ratio for $\mathrm{N}$ (representing export intensity for $\mathrm{Si}$ and $\mathrm{N}$ respectively). When the 1- $\int \mathrm{D}: \int \mathrm{P}$ values obtained from our model are plotted versus the f-ratio for each site (obtained from Nelson et al. [2002] for the Southern Ocean and from Falkowski et al. [2003] for the other sites) (Figure 4), the silica pump appears to be most pronounced at APFP and NACC sites. At the EqPac site, $1-\int \mathrm{D}: \int \mathrm{P}$ is close to 0.12 , whereas the f-ratio is between 0.1 and 0.17 [Dugdale et al., 1992; McCarthy et al., 1996]. Since 1- $\int \mathrm{D}: \int \mathrm{P}$ is less than or equal to the f-ratio at this site, it would appear that the silicate pump is weak or nonexistent.

[27] The silicate pump will be most pronounced under the following two conditions: (1) when particle formation is extensive enough to induce rapid export from the mixed layer, and (2) when Si and N cycling are decoupled, so that more $\mathrm{Si}$ is exported relative to $\mathrm{N}$. To simplify the model as much as possible, we pooled aggregates and fecal pellets into a single group to reconstruct $\mathrm{bSiO}_{2}$ fluxes. This simplification may lead to some inaccuracies, as grazing (i.e., fecal pellet production) and aggregation can have very different effects on the silicate pump [see Ragueneau et al., 2006]. While grazers assimilate $\mathrm{C}$ and $\mathrm{N}$ from diatom material, $\mathrm{bSiO}_{2}$ passes through the gut quasi-inertly, leading to a fivefold increase in the $\mathrm{Si} / \mathrm{C}$ ratio as the material is egested [Cowie and Hedges, 1996; Tande and Slagstad, 1985]. By contrast, diatoms that are incorporated within aggregates rather than ingested by zooplankton would tend to remain alive for a longer time, fixing their $\mathrm{Si} / \mathrm{C}$ ratio at a relatively constant value [Moriceau et al., 2007]. Despite this caveat, with our simple model we can at least identify sites with a high flux of fast-sinking particles, and see that 1- $\int \mathrm{D}: \int \mathrm{P}$ (at $100 \mathrm{~m}$ ) is highest at sites with the most seasonality (Figure 3). Clearly, particle formation at the end of blooms is a key factor controlling the silicate pump. Further investigation of aggregation dynamics is crucial for understanding temporal and spatial variations in the strength of the silicate pump, as well as the role of diatoms in the biological carbon pump [e.g., Ragueneau et al., 2006].

\subsection{Impact on the Geochemistry of the Seafloor}

[28] Our results have important implications for the calibration of $\mathrm{bSiO}_{2}$ mass accumulation rates (MAR) as a proxy of paleoproductivity [Ragueneau et al., 2000]. Larger opal MAR need not necessarily be ascribed to higher surface productivity. At the POOZ site (Figure 2), for example, a doubling in the $\mathrm{bSiO}_{2}$ rain rate can be achieved without any change in surface $\mathrm{bSiO}_{2}$ production, through either (1) a doubling in the incorporation of $\mathrm{bSiO}_{2}$ into large particles (i.e., from $20 \%$ to $40 \%$ ), (2) a 3.33 -fold increase in the LP sinking rate (from 30 to $100 \mathrm{~m} \mathrm{~d}^{-1}$ ), or (3) a 2.67-fold decrease in the LP dissolution rate from 0.04 to $0.015 \mathrm{~d}^{-1}$. These ranges in values are all realistic, and a small variation in one of them can significantly increase the amount of $\mathrm{bSiO}_{2}$ reaching the seafloor. Furthermore, these 3 factors are not necessarily independent and can therefore have additive effects. For example, incorporation into large particles would most likely increase both the particle sinking rate and decrease the $\mathrm{bSiO}_{2}$ dissolution rate [Moriceau et al., 2007]. Clearly, improving our understanding of how siliceous sediments accumulate requires proper consideration of particle formation and biogeochemical cycling in sinking particles. This is crucial not only for determining the depth of $\mathrm{bSiO}_{2}$ dissolution in the water column, but also the extent of silica burial in sediments [Gallinari et al., 2002; Khalil et al., 2007].

\section{Conclusions and Perspectives}

[29] In this paper, we have combined sinking and silica dissolution rates [Schultes, 2004; Moriceau et al., 2007] for three types of siliceous particles (diatoms as free cells, incorporated into zooplankton fecal pellets, or into aggregates) to reconstruct theoretical downward profiles of $\mathrm{bSiO}_{2}$ fluxes. By applying a simple advection-reaction model to 8 sites of the world ocean where annual estimates of $\mathrm{bSiO}_{2}$ production are available [Ragueneau et al., 2002], 
we were able to fit these theoretical profiles to measured $\mathrm{bSiO}_{2}$ fluxes derived from sediment trap data. Such an approach allowed us to derive the sinking rates of particles and partitioning of $\mathrm{bSiO}_{2}$ between freely suspended diatoms and large particles. When diatoms are incorporated into large particles via aggregation or incorporation into fecal pellets, this can impact $\mathrm{bSiO}_{2}$ recycling and possibly other elements like $\mathrm{C}$ and N. Further experimentation would be needed, however, to assess this last point.

[30] The competition between recycling in surface waters and export to depth is controlled by the intensity of particle formation rather than by the extent of dissolution in surface waters. For $\mathrm{bSiO}_{2}$ incorporated into sinking aggregates and fecal pellets, export is much faster than dissolution. Therefore the extent of dissolution in surface waters depends primarily on the amount of diatom cells that remain freely suspended and can subsequently be degraded by bacteria [Bidle and Azam, 1999]. Thus, even ballasted by its frustule, a diatom would be recycled if not incorporated into fastsinking aggregates or fecal pellets.

[31] This finding also has implications for the use of opal MAR as a proxy of paleoproductivity, which should account not only for the production signal, but also the extent of incorporation into large particles. Furthermore, just as $\mathrm{bSiO}_{2}$ preservation depends on the types of particles transporting diatoms toward the seafloor, it likely affects $\mathrm{C}$ preservation as well. Further investigation is needed of the extent of $\mathrm{C}$ recycling within aggregates and fecal pellets, as this has major implications for $\mathrm{C}$ export and benthic food webs.

[32] Our model demonstrated that dissolution in surface waters is extremely high at the EqPac site, most likely owing to the small percentage of $\mathrm{bSiO}_{2}$ production being incorporated, on an annual basis, into large sinking particles (Table 2). This result does not support the idea of a strong silicate pump in the equatorial Pacific, as previously suggested by Dugdale et al. [1995]. Rather, it appears that such a mechanism would be most applicable at highly seasonal sites like NACC or APFP where the fraction of $\mathrm{bSiO}_{2}$ production that is exported from the surface layer is highest (Figure 3). At such locations, the efficiency of the silica pump will depend upon the relative fates of $\mathrm{Si}$ and $\mathrm{N}$ in sinking particles. Since aggregation and incorporation into fecal pellets may have very distinct influences on Si and $\mathrm{N}$ decoupling during sinking [Ragueneau et al., 2006], differentiating between these two transport pathways is essential for improving our understanding of the functioning of the silicate pump, the role of diatoms in the biological pump, and the nutritional properties of particles supporting deep-sea food webs.

[33] Acknowledgments. We are grateful to Monique Briand for her technical assistance with graphics. Thanks to Sorcha Ni Longphuirt, Cindy Lee and Lynn Abramson who kindly commented on this paper and corrected it from the English mistakes. The authors acknowledge NODC (Levitus) World Ocean Atlas 1998 for their data provided by the NOAACIRES Climate Diagnostics Center, Boulder, Colorado, USA, from their Web site at http://www.cdc.noaa.gov/. This work has been funded by the EU which is greatly acknowledged, partly through the ORFOIS (EVK2CT2001-00100) project and partly through the Si-WEBS (HPRN-CT-200200218) Research Training network of the Marie Curie program. This is contribution 1038 of the IUEM.

\section{References}

Alldredge, A. L., and C. Gotschalk (1988), In situ settling behaviour of marine snow, Limnol. Oceanogr., 33, 339-351.

Armstrong, R. A., C. Lee, J. I. Hedges, S. Honjo, and S. G. Wakeham (2002), A new, mechanistic model for organic carbon fluxes in the ocean based on the quantitative association of POC with ballast minerals, Deep Sea Res., Part II, 49, 219-236.

Aumont, O., E. Maier-Reimer, S. Blain, and P. Monfrey (2003), An ecosystem model of the global ocean including $\mathrm{Fe}, \mathrm{Si}, \mathrm{P}$ colimitations, Global Biogeochem. Cycles, 17(2), 1060, doi:10.1029/2001GB001745.

Berger, W. H., and G. Wefer (1990), Export production: seasonality and intermittency, and paleoceanographic implications, Palaeogeogr. Palaeoclimatol. Palaeoecol., 89, 245-254.

Bidle, K. D., and F. Azam (1999), Accelerated dissolution of diatom silica by marine bacterial assemblages, Nature, 397, 508-512

Bidle, K. D., M. Manganelli, and F. Azam (2002), Regulation of oceanic silicon and carbon preservation by temperature control on bacteria, Science, 298, 1980-1984.

Bienfang, P. K. (1981), Sinking rate of heterogeneous, temperate phytoplankton populations, J. Plankton Res., 3, 235-253.

Blain, S., P. Tréguer, and M. Rodier (1999), Stocks and fluxes of biogenic silica in the western oligotrophic equatorial Pacific, J. Geophys. Res., 104, 3357-3367.

Brzezinski, M. A., D. M. Nelson, V. M. Franck, and D. E. Sigmon (2001), Silicon dynamics within an intense open-ocean diatom bloom in the Pacific Sector of the Southern Ocean, Deep Sea Res., Part II, 48, 3997-4018.

Brzezinski, M. A., J. L. Jones, K. D. Bidle, and F. Azam (2003), The balance between silica production and silica dissolution in the sea: Insights from Monterey Bay, California, applied to the global data set, Limnol. Oceanogr., 48, 1846-1854.

Buesseler, K. O. (1998), The decoupling of production and particulate export in the surface ocean, Global Biogeochem. Cycles, 12, 297-310.

Cowie, G. L., and J. I. Hedges (1996), Digestion and alteration of the biochemical constituents of a diatom (Thalassiosira weissflogii) ingested by an herbivorious copepod (Calanus pacificus), Limnol. Oceanogr., 41, $581-594$.

Cushing, D. H. (1989), A difference in structure between ecosystems in strongly stratified waters and in those that are only weakly stratified, J. Plankton Res., 11, 1-13.

Dugdale, R. C., and F. P. Wilkerson (1998), Silicate regulation of new production in the equatorial Pacific upwelling, Nature, 391, 270-273.

Dugdale, R. C., F. P. Wilkerson, R. T. Barber, and F. P. Chavez (1992), Estimating new production in the equatorial Pacific Ocean at $150^{\circ} \mathrm{W}$, J. Geophys. Res., 97, 681-686.

Dugdale, R. C., F. P. Wilkerson, and H. J. Minas (1995), The role of a silicate pump in driving new production, Deep Sea Res., Part I, 42, 697719.

Falkowski, P. G., E. A. Laws, R. T. Barber, and J. W. Murray (2003), Phytoplankton and their role in primary, new and export production, in Ocean Biogeochemistry, edited by M. J. R. Fasham, pp. 99-121, Springer, Berlin.

Fujii, M., and F. Chai (2005), Effects of biogenic silica dissolution on silicon cycling and export production, Geophys. Res. Lett., 32, L05617, doi:10.1029/2004GL022054.

Gallinari, M., O. Ragueneau, L. Corrin, D. J. Demaster, and P. Tréguer (2002), The importance of water column processes on the dissolution properties of biogenic silica in deep sea-sediments: I. Solubility, Geochim. Cosmochim. Acta, 66, 2701-2717.

Greenwood, J., V. W. Truesdale, and A. R. Rendell (2001), Biogenic silica dissolution in seawater-In vitro chemical kinetics, Prog. Oceanogr., 48, $1-23$.

Kemp, A. E. S., J. Pike, R. B. Pearce, and C. B. Lange (2000), The "Fall dump"-A new perspective on the role of a "shade flora" in the annual cycle of diatom production and export flux, Deep Sea Res., Part I, 47, $2129-2154$

Kemp, A. E. S., R. B. Pearce, I. Grigorov, J. Rance, C. B. Lange, P. Quilty, and I. Salter (2006), Production of giant marine diatoms and their export at oceanic frontal zones: Implications for $\mathrm{Si}$ and $\mathrm{C}$ flux in stratified oceans, Global Biogeochem. Cycles, 20, GB4S04, doi:10.1029/ 2006GB002698

Khalil, K., C. Rabouille, M. Gallinari, and O. Ragueneau (2007), Constraining biogenic silica dissolution in marine sediments: A comparison between diagenetic models and experimental dissolution rates, Mar Chem, doi:10.1016/j.marchem.2006.12.004, in press.

Klaas, C., and D. E. Archer (2002), Association of sinking organic matter with various types of mineral ballast in the deep sea: Implications for the rain ratio, Global Biogeochem. Cycles, 16(4), 1116, doi:10.1029/ $2001 \mathrm{~GB} 001765$ 
Lampitt, R. S., K. Kiriakoulakis, O. Ragueneau, A. Vangriesheim, and G. Wolff (2001), Material supply to the abyssal seafloor in the northeast Atlantic, Prog. Oceanogr., 50, 27-63.

Lawson, S. D., D. C. Hurd, and H. Stuart Pankratz (1978), Silica dissolution rates of decomposing phytoplankton assemblages at various temperature, Am. J. Sci., 278, 1373-1393.

Leynaert, A., P. Tréguer, C. Lancelot, and M. Rodier (2001), Silicon limitation of biogenic silica production in the equatorial Pacific, Deep Sea Res., Part I, 48, 639-660.

Mann, K. H., and J. R. N. Lazier (Eds.) (1996), Dynamics of Marine Ecosystems: Biological- Physical Interactions in the Oceans, 394 pp. Blackwell Sci., Malden, Mass.

McCarthy, J. J., C. Garside, J. L. Nevins, R. T. Barber, and J. W. Murray (1996), New production along the $140^{\circ} \mathrm{W}$ in the equatorial Pacific during and following the 1992 El Niño event, Deep Sea Res., Part II, 43, 1065-1093.

Moriceau, B., M. Garvey, U. Passow, and O. Ragueneau (2007), Evidence for reduced biogenic silica dissolution rates in diatom aggregates, Mar Ecol. Prog. Ser., 333, 129-142.

Nelson, D. M., P. Tréguer, M. A. Brzezinski, A. Leynaert, and B. Quéguiner (1995), Production and dissolution of biogenic silica in the ocean: Revised global estimates, comparison with regional data and relationship to biogenic sedimentation, Global Biogeochem. Cycles, 9, 359-372.

Nelson, D. M., et al. (2002), Vertical budgets for organic carbon and biogenic silica in the pacific sector of the Southern Ocean, 1996-1998, Deep Sea Res., Part II, 49, 1645-1674.

Officer, C. B., and J. H. Ryther (1980), The possible importance of silicon in marine eutrophication, Mar. Ecol. Prog. Ser, 3, 83-91.

Passow, U. (2004), Switching perspectives: Do mineral fluxes determine particulate organic carbon fluxes or vice versa?, Geochem. Geophys. Geosyst., 5, Q04002, doi:10.1029/2003GC000670.

Pondaven, P., C. Fravalo, D. Ruiz-Pino, P. Tréguer, B. Quéguiner, and C. Jeandel (1998), Modelling the silica pump in the Permanently Open Ocean Zone of the Southern Ocean, J. Mar. Syst., 17, 587-619.

Ragueneau, O., et al. (2000), A review of the Si cycle in the modern ocean: Recent progress and missing gaps in the application of biogenic opal as a paleoproductivity proxy, Global Planet. Change, 26, 317-365.

Ragueneau, O., N. Dittert, P. Pondaven, P. Tréguer, and L. Corrin (2002), $\mathrm{Si} / \mathrm{C}$ decoupling in the world ocean: Is the Southern Ocean different? Deep Sea Res., Part II, 49, 3127-3154.

Ragueneau, O., S. Schultes, K. Bidle, P. Claquin, and B. Moriceau (2006), $\mathrm{Si}$ and $\mathrm{C}$ interactions in the world ocean: Importance of ecological processes and implications for the role of diatoms in the biological pump, Global Biogeochem. Cycles, 20, GB4S02, doi:10.1029/2006GB002688.

Rickert, D., M. Schlüter, and K. Wallmann (2002), Dissolution kinetics of biogenic silica from the water column to the sediments, Geochim. Cosmochim. Acta, 66, 439-455.

Ridgwell, A. J., A. J. Watson, and D. E. Archer (2002), Modeling the response on the oceanic $\mathrm{Si}$ inventory to perturbation, and consequences for atmospheric $\mathrm{CO}_{2}$, Global Biogeochem. Cycles, 16(4), 1071 doi:10.1029/2002GB001877.
Rinaldi, A., R. A. Vollenweider, G. Montanari, C. R. Ferrari, and A. Ghetti (1995), Mucilages in Italian seas: The Adriatic and Thyrrhenian Seas, 1988-1991, Sci. Total Environ., 165, 165-183.

Sarmiento, J. L., J. Dunne, and R. A. Armstrong (2004), Do we now understand the ocean's biological pump?, U.S. JGOFS Newsl., 12(4), $1-5$.

Schultes, S. (2004), The role of mesozooplankton grazing in the biogeochemical cycle of silicon in the Southern Ocean, Ph.D. thesis, 168 pp., Univ. Bremen, Bremen, Germany.

Smayda, T. J. (1970), The sinking and suspension of phytoplankton in the sea, Oceanogr. Mar. Biol. Annu. Rev., 8, 353-414.

Smetacek, V. (1999), Diatoms and the ocean carbon cycle, Protist, 150 $25-32$.

Smith, C. R., D. J. Hoover, S. E. Doan, R. H. Pope, D. J. Demaster, F. C. Dobbs, and M. A. Altabet (1996), Phytodetritus at the abyssal seafloor across $10^{\circ}$ of latitude in the central equatorial Pacific, Deep Sea Res. Part II, 43, 1309-1338.

Smith, C. R., S. L. Minks, A. G. Glover, D. J. Demaster, and P. Y. Sumida (2002), FOODBANCS on the Antarctic Peninsula Shelf: The benthic food bank hypothesis and the seasonal deposition pulse, Eos Trans. $A G U, 83(4)$, Ocean Sci. Meet. Suppl., Abstract OS31N-02.

Smith, K. L.Jr., R. J. Baldwin, D. M. Karl, and A. Boetius (2002), Benthic community responses to pulses in pelagic food supply: North Pacific subtropical Gyre, Deep Sea Res., Part I, 49, 971-990.

Tande, K. S., and D. Slagstad (1985), Assimilation efficiency in herbivorous aquatic organisms-The potential of the ratio method using ${ }^{14} \mathrm{C}$ and biogenic silica as markers, Limnol. Oceanogr., 30, 1090-1093.

Thornton, D. C. O. (2002), Diatom aggregation in the sea: Mechanisms and ecological implications, Eur. J. Phycol., 37, 149-161.

Tréguer, P., D. M. Nelson, A. J. V. Bennekom, D. J. Demaster, A. Leynaert, and B. Quéguiner (1995), The silica balance in the world ocean A reestimate, Science, 268, 375-379.

Turner, J. T. (2002), Zooplankton faecal pellets, marine snow and sinking phytoplankton blooms, Aquat. Microb. Ecol., 27, 57-102.

Van Cappellen, P., S. Dixit, and J. Van Beusekom (2002), Biogenic silica dissolution in the oceans: Reconciling experimental and field-based dissolution rates, Global Biogeochem. Cycles, 16(4), 1075, doi:10.1029/ 2001GB001431.

Wassmann, P., L. Hansen, I. J. Andreassen, C. W. Riser, and J. Urban-Rich (1999), Distribution and sedimentation of faecal pellets on the Nordvestbanken shelf, northern Norway, in 1994, Sarsia, 84, 239-252.

Yoder, J. A., S. G. Ackelson, R. T. Barber, P. Flamant, and W. M. Balch (1994), A line in the sea, Nature, 371, 689-692.

M. Gallinari, B. Moriceau, O. Ragueneau, and K. Soetaert, Institut Universitaire Européen de la Mer, UMR CNRS 6539, Place Copernic, Technopôle Brest-Iroise, F-29280 Plouzané, France. (moriceau@univ-brest.fr) 